\title{
IDENTIFYING DOMINANT RUNOFF PROCESSES AT A REGIONAL SCALE - A GIS - BASED APPROACH
}

\section{Fagbohun Babatunde Joseph ${ }^{1}$, Olabode Oluwaseun Franklin², Adebola Abiodun Olufemi ${ }^{3}$}

\begin{abstract}
Identifying landscapes with similar hydrological characteristics is useful for the determination of dominant runoff process (DRP) and flood prediction. Several approaches used for DRP-mapping differ in respect to time and data requirement. Manual approaches based on field investigation and expert knowledge are time consuming and difficult to implement at regional scale. Automatic GIS-based approach on the other hand require simplification of data but are easier to implement and it is applicable on regional scale.

In this study, GIS-based automated approach was used to identify the DRPs in Anambra area. The result showed that Hortonian Overland Flow (HOF) has the highest coverage of $1508.3 \mathrm{Km}^{2}(33.5 \%)$ followed by Deep Percolation (DP) with coverage of $1455.3 \mathrm{Km}^{2}(32.3 \%)$. Subsurface Flow (SSF) is the third dominant runoff process covering $920.6 \mathrm{Km}^{2}(20.4 \%)$ while Saturated Overland Flow (SOF) covers the least area of $618.4 \mathrm{Km}^{2}(13.7 \%)$ of the study area. The result reveal that considerable amount of precipitated water would be infiltrated into the subsurface through deep percolation process contributing to groundwater recharge in the study area. However, it is envisaged that HOF and SOF will continue to increase due to the continuous expansion of built-up area. With the expected increase in HOF and SOF and the change in rainfall pattern associated with perpetual problem of climate change, it is paramount that groundwater conservation practices be considered to ensure continued sustainable utilization of groundwater in the study area.
\end{abstract}

Keywords: DRP, GIS, Remote sensing, Groundwater sustainability

\footnotetext{
${ }^{1}$ Assistant Lecturer, Department of Remote Sensing and Geoscience Information System, Federal University of Technology, P.M.B 704, Akure, Nigeria.

Corresponding author's emails: jfahb328@gmail.com; bjfagbohun@futa.edu.ng

Phone: +2347035782585

${ }^{2}$ Assistant Lecturer, Department of Applied Geology, Federal University of Technology, P.M.B 704, Akure, Nigeria, email: seunwhyte@yahoo.co.uk

3 Lecturer II, Department of Remote Sensing and Geoscience Information System, Federal University of Technology, P.M.B 704, Akure, Nigeria, email: aodebola@futa.edu.ng; collinola@gmail.com
} 


\section{Introduction}

Determination of Dominant Runoff Processes (DRPs) is essential towards planning water conservation measures such as identification of groundwater recharge zones, reduction of the flooding and erosion hazards, as well as monitoring of sedimentation in downstream areas. Runoff is the net liquid water supplied to channels after evaporation, interception, surface retention, infiltration and percolation to underlying aquifers (Aladejana et al., 2016; Sharma et al., 2001) and it is also the main force behind sheet erosion (Fagbohun et al., 2016). The knowledge of the spatial distribution of the DRPs in a catchment allows detailed understanding of runoff generation and offers a tool to determine the contributing areas under different rainfall characteristics and initial catchment conditions (Bonell, 1998). Expert knowledge regarding the different runoff processes that can occur on a catchment can help improve the hydrological simulations particularly for ungauged basins.

Several runoff processes can occur on one site, however the dominant one is that which contributes most to runoff, hence other processes can be neglected (Müller et al., 2009; Scherrer and Naef, 2001). Theprocess which dominates depends on the site characteristics and the rainfall event. The DRP on a site is the process that contributes most to runoff for a given rainfall event (Naef et al., 2002)

DRP can be classified as Hortonian Overland Flow (HOF), Saturated Overland Flow (SOF), Subsurface Flow (SSF) and Deep Percolation (DP) (Scherrer and Naef, 2003). Overland flow is the movement of water over the land, downslope toward a surface water body. The HOF occur when rainfall intensity exceeds the rate of infiltration into the ground and all depression storage has been filled. Water accumulates on the soil and starts moving downslope, due to gravity, towards the hydrographic network. It commonly occurs in arid and semi-arid regions where rainfall intensities are high and soil infiltration has been reduced. It is also the dominant process in built-up areas where the ground is paved or soils have become compacted. SOF on the other hand occur when soil is saturated and depression storage are filled due to groundwater uplifting, base flow, and lateral subsurface water discharges, the continued downpour of rain result in SOF. The antecedent moisture content of soil is a major factor that influences the time it takes soil to become saturated (Glinsli et al., 2001). SSF generally results if an impermeable horizon or impermeable bedrock occurs on a steep slope with very shallow or less shallow soil and an effective system of lateral flow paths. DP is however expected on permeable and thick soils or on permeable shallow soils with very permeable subsoil and bedrock (Scherrer and Naef, 2003). 
Several methods have been developed to identify and delineate the spatial extent of areas where a specific runoff process occurs particularly in micro-scale basin (Faeh, 1997; Scherrer and Naef, 2001) which are suitable for regionalization purposes. DRP classifications may be manual or automatic. While manual approaches are based on extensive field investigations and interpretation and upscaling of the results based on expert knowledge, however automatic methods on the other hand generally rely on GIS and on algorithms based on simplifications of expert knowledge (Antonetti et al., 2016). Automatic approaches differ in the type of data requirement. Some rely solely on topographic information (Gharari et al., 2011) while others employ ali available information (Schmocker-Fackel et al., 2007)

The result of both manual and automated approaches is a DRP-map which represent the spatial distribution of the hydrological behaviour of the soil during prolonged rainfall events (Müller et al., 2009). However, the resulting DRP classes of the methods differ. While all methods distinguish between HOF and SOF and between SSF and DP, several approaches further subdivide SOF process as $\mathrm{D}_{\mathrm{SOF} 1}$, $\mathrm{D}_{\mathrm{SOF} 2}$ and $\mathrm{D}_{\mathrm{SOF} 3}$ and $\mathrm{SSF}$ process as $\mathrm{D}_{\mathrm{SSF} 1}, \mathrm{D}_{\mathrm{SSF} 2}$ and $\mathrm{D}_{\mathrm{SSF}}$ based intensity (Antonetti et al., 2016), where the numbers from 1 to 3 represent the delay in their reaction to rainfall, with 1 representing an almost immediate reaction, 2 a slightly delayed one, and 3 a strong delayed one (Müller et al., 2009; Scherrer and Naef, 2003; Schmocker-Fackel et al., 2007).

In this study, DRP was evaluated using GIS-based automatic geostatistical (GIS-DRP) approach developed by Müller et al (2009). This approach was preferred because it requires less input data as well as shorter computation time with higher accuracy when compared to other GIS based approaches (Müller et al., 2009)

\section{STUDY AREA}

The study area is Anambra state which lies between latitudes $5^{\circ} 40^{\prime} \mathrm{N}$ and $6^{\circ} 35^{\prime} \mathrm{N}$ and longitude $7^{\circ} 10^{\prime} \mathrm{E}$ and $7^{\circ} 20^{\prime} \mathrm{E}$. Anambra is characterized by tropical climatic condition with rainy and dry season. The rainy season span between the months of March to September. The dry season span between the months of November to February and it is accompanied by harmattan dry winds. The annual rainfall is between $1400 \mathrm{~mm}$ in the northern part to around $2500 \mathrm{~mm}$ in the southern part while average annual temperature is about $33^{\circ} \mathrm{C}($ Onwuka et al., 2012). The vegetation is tropical rain forest intermingled by large overgrowth of shrubs, stunted trees and tall elephant grasses (Offodile, 2014)

The study area is characterized by varied terrain with highland of moderate elevation occurring in the south while low plains lie to the east, west 
and north. The plains are almost featureless, however there are occasional broad undulations, rising above the flood plains. The geology of the area has an influence on runoff and erosion process with the highlands with considerable stable lithology resisting development of gullies but provide aggressive runoff which move download to devastate lowland areas. (Ofomata, 1981; Igwe, 2012).

The study area falls within the Anambra Basin which is underlain by sedimentary rocks. The Aptian-Santonian folding and uplift of Abakaliki region has been linked with the evolution of the basin which resulted in the dislocation of the depocentre into Anambra platform and Afikpo region (Oboh-Ikuenobe et al., 2005). The Asu River Group, Eze Aku Group and Agbani Sandstone/Awgu Shale constitute the lithology's in the Abakaliki region prior to folding and uplift. The evolution of Anambra Basin resulted in the deposition of Nkporo Group during the Campano-Maastrichtian, Mamu and Ajali Formations during the Maastrichtian, Nsukka and Imo Formation during the Palaeocene, Ameki Group during the Eocene and Ogwashi-Asaba Formation during the Oligocene (Nwajide, 1990).

Nkporo Group comprises of Nkporo Shale, Oweli Sandstone and Enugu Shale. It is overlain by Mamu Formation consisting of shale, coal and sandy shale while Ajali Formation which overlie Mamu Formation is a thick friable poorly sorted white sandstone (Gideon et al., 2014; Reyment, 1965). Ajali Sandstone is overlain by Nsukka Formation which vary from coarse to medium grained sandstones at the base to a sequence of well-bedded blue clays, finegrained sandstones and carbonaceous shale with limestone at the top while the overlying Imo Formation comprises of biue-grey clays, shale and black shales with bands of calcareous sandstone, marl and limestone (Oboh-Ikuenobe et al., 2005). The Ameki Group comprises of Nanka sand, Nsugbe and Ameki Formations. The Ameki Formation is an alternating sequence of shale, sandy shale, clayey sandstone and fine-grained fossiliferous sandstone with thin limestone bands (Oboh-Ikuenobe et al., 2005; Reyment, 1965). The OgwashiAsaba Formation comprises of alternating sequence of coarse-grained sandstone, lignite seams, and light coloured clays of continental origin (ObohIkuenobe et al., 2005).

\subsection{Hydrology and hydrogeology of the study area}

Anambra basin to which the study area belong appears to represent an inverted triangular depression covering about $30,000 \mathrm{Km}^{2}$ with its base along the Benue river axis and its apex pointing southwards toward Onitsha on the main trunk of River Niger (Offodile, 2014). The basin is drained mainly by Anambra River and its tributaries. The drainage pattern is dendritic to subdendritic with the rivers emptying into river Niger on the western part of the 
area. The Anambra drainage system (Figure 2) flows approximately northeastsouthwest joining the main trunk of River Niger at an acute angle.

Hydrogeological, the most important aquifers formation in the Anammbra basin is the Ajali Formation. The Mamu and Nkporo Formations consist majorly of clays, shales and coal seams, hence can best be considered as aquicludes or aquitards (Offodile, 2014).

\section{DATA AND METHODS}

Many approaches exist for determining the DRP of an area. However, the approach developed by Scherrer and Naef (2003) based on large number of field- and sprinkling experiments formed the basis for developing process decision schemes to determine DRPs on a soil profile which occur after prolonged rainfall events. The data required for the method comprise sixteen (16) datasets: soil profiles; soil maps; topographical maps; geo-morphological

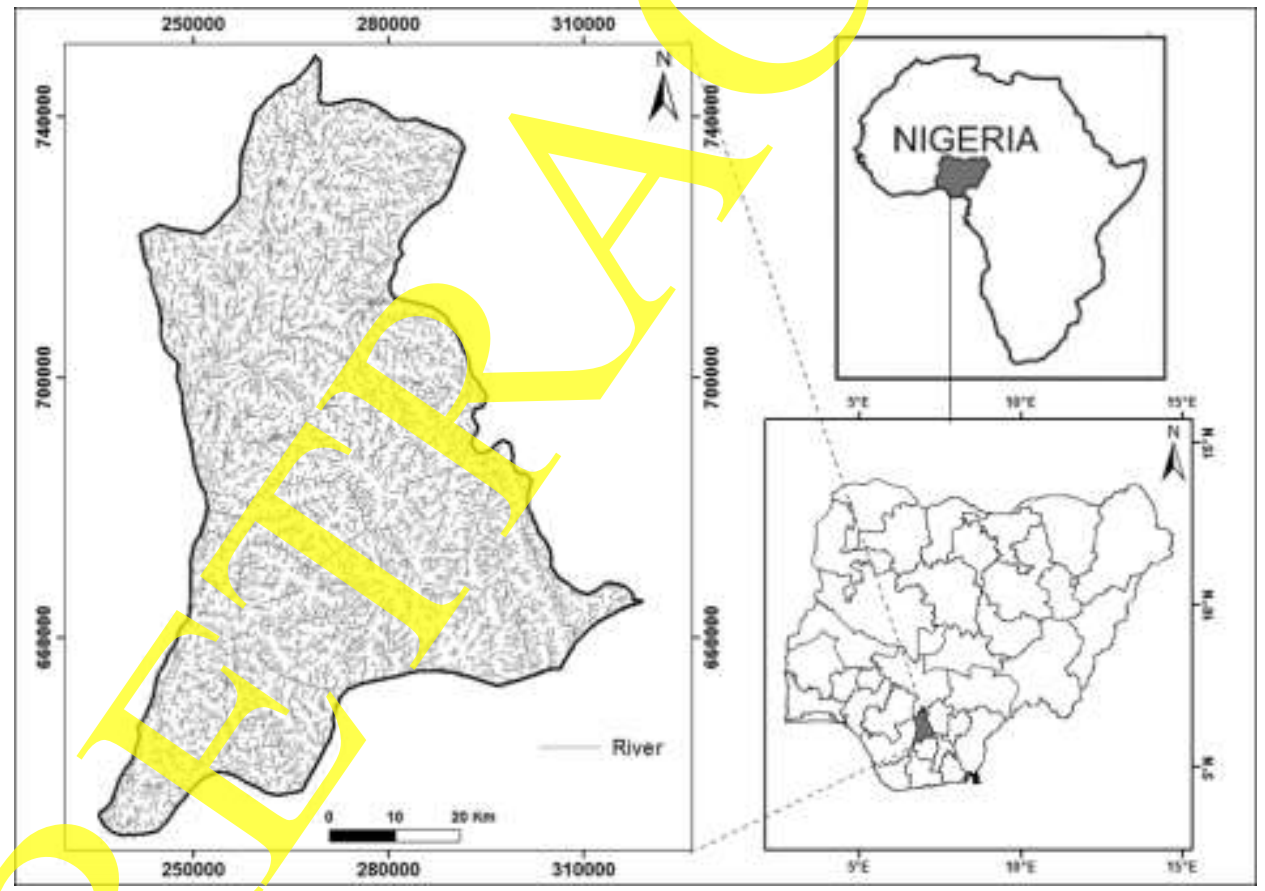

Fig. 1. Drainage pattern of the study area. Inset Africa and Nigeria

maps; vegetation maps; geological maps; hydrological maps; geo-technical maps; geo-ecological maps; drilling points with soil description; infiltration 
tests; digital maps (ATKIS); forestry maps; agricultural land evaluation; remote sensing data and drainage plans (Müller et al., 2009). Scherrer and Naef (2003) indicated the limitations of their approach is that rains of low intensity infiltrate into the soil predominantly by matrix flow and their scheme does not apply to such conditions. Field experiments emphasized the important role of the nature of the surface topsoil interface infiltration and runoff formation. Because this interface is more complex on arable land and in forests than on grassland, special decision schemes are required for these other land use types. Hydrological data cannot be used to calibrate or validate the obtained dominant runoff processes. A geo-statistical or statistical analysis of DRP without the use of detailed soil maps could offer insight into their regionalization potential (Müller et al., 2009).

Müller et al. (2009) therefore proposed a simplification of SchmockerFackel's et al. (2007) approach based on GIS that is valid for prolonged rainfall events. The method combines information on the permeability of the geological substratum, slope and land use, but excludes soil information. The result is the same DRP classes as those proposed by Scherrer and Naef (2003). Geostatistical analysis (GIS-DRP) for the delineation of DRPs with respect to regionalization require three basic datasets in terms of permeability: simplified geological map, digital elevation model and land use map. The method involves using a digital terrain modelling (DTM) analysis to identify slopes classes, followed classifying the geological substrata as either permeable or impermeable and then classification of land use. The three factors are then combined to obtain the DRP. Hümann and Müller (2013) extended the approach proposed by Müller et al. (2009) to forested areas and to different event types, however Müller et al.'s (2009) approach was used in this study.

In order to identify the DRPs in the study area adopting the method proposed by Müller et al. (2009), the following data were used: SRTM with spatial resolution of $30.86 \mathrm{~m}$ ( 1 Arc-Second), Landsat 8 with $30 \mathrm{~m}$ spatial resolution and geological map. The SRTM and Landsat 8 were downloaded from http://earthexplorer.usgs.gov/.

GIS-DRP makes use of a simplification of the procedure developed by Scherrer and Naef (2003). The simplification is based on assumption that the DRP are mainly dependent on slope and the permeability of the substratum. The first step in the generation of GIS-DRP is to generate the slope classes according to the original decision scheme for field campaigns to determine dominant runoff processes (Scherrer and Naef, 2003) from the DEM. Stream network was also generated from the DEM. In the second step geological substrata of the area are classified into permeable or impermeable. Permeability of the substratum is based on the lithology and geo-hydrological characteristic such as primary porosity and secondary porosity such as fractures. The land use/cover of the area 
was derived from Landsat data. All data were converted to vector and finally the permeability layer is linked to the slope classes and the developed land use map to determine a DRP for each of the polygons.

\subsection{Land use/cover}

Land use/cover is an important factor which influence runoff type occurring in an area. The type of use to which a land is subjected to can either support or reduce the development of runoff. Remotely sensed images provide reliable information on land use/cover. The land use/cover types in the study area was derived from Landsat 8 data.

The land use/cover types were obtained by classification of the Landsat data through supervised classification approach using maximum likelihood method in ENVI software. The land use/cover types in the study area are: arable farm, bare ground, built up, forest and waterbody as shown in Figure 2A. Arable land covers the largest area within the study area. The spatial coverage of the land use/cover types is presented in Table

Table 1 . Area covered by different land use/cover classes in the study area

\begin{tabular}{lll}
\hline Land use/cover & $\begin{array}{l}\text { Area } \\
\mathrm{km}^{2}\end{array}$ & $\begin{array}{l}\text { Percent area } \\
\%\end{array}$ \\
\hline Arable land & 1596.3 & 35.2 \\
Bare ground & 151.7 & 3.4 \\
Built up & 1500.8 & 33.2 \\
Forest & 1219.6 & 26.9 \\
Waterbody & 58.4 & 1.3 \\
\hline
\end{tabular}

\subsection{Slope}

The gradient of slope is one of the factors that directly influence the runoff and infiltration of rainfall in that steeper slopes generate high runoff (Selvam et al., 2015). Flat areas with gentle slope are capable of holding rainfall, thereby enabling infiltration of water and reduction of formation of overland flow, whereas in areas where the slope amount is high, there will be high runoff due to rapid development of overland flow. The slope of the area was calculated in percentage using the surface analysis tool of spatial analyst in ArcGIS. The computed slope was reclassified based on its influence on formation of DRP as specified by Müller et al. (2009) (Figure 2B). The spatial coverage of the slope classes is presented in Table 2 . 
Table 2.Slope classes in the study area

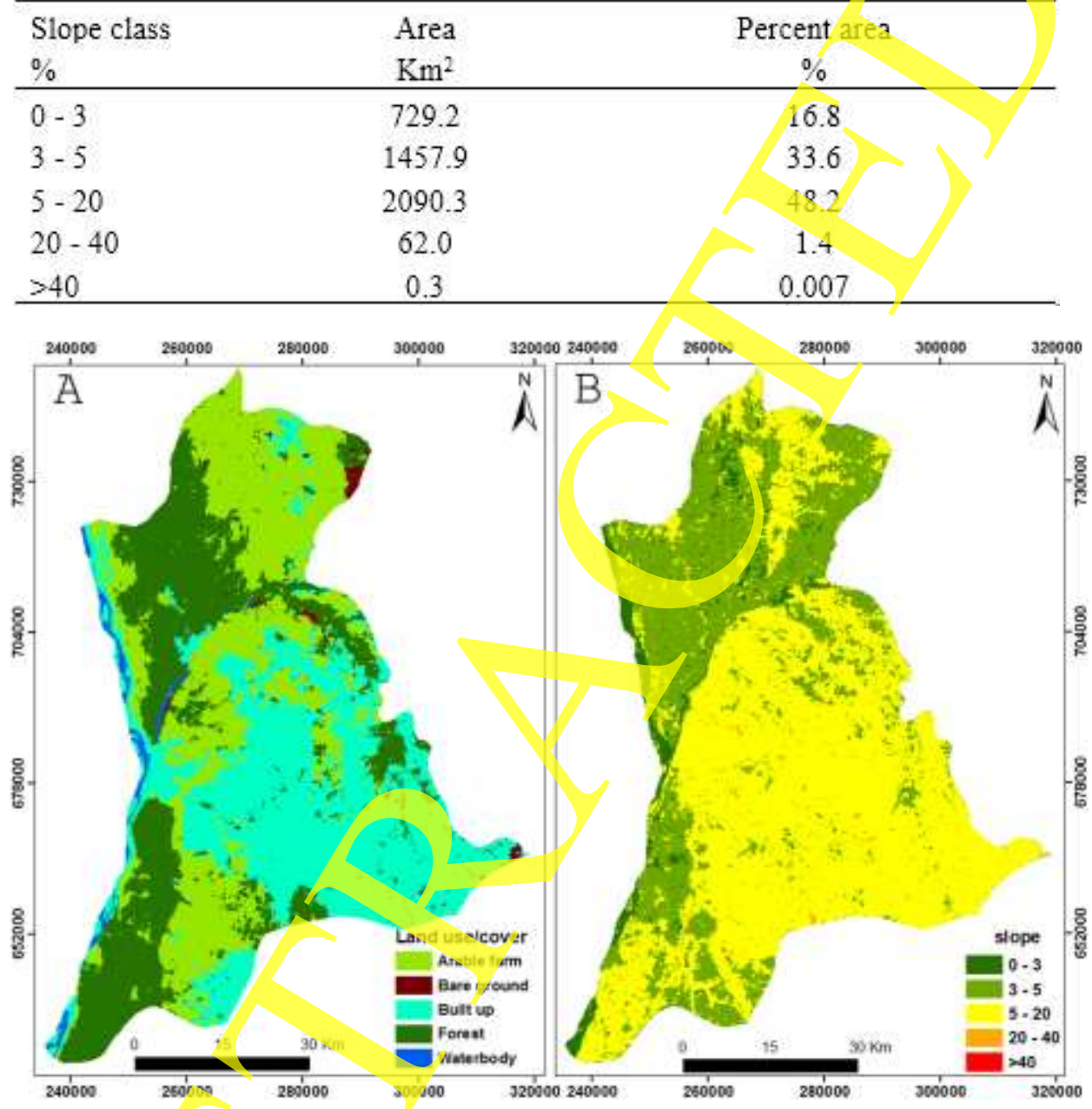

Fig.2.(A) Land use/cover (B) Slope

\subsection{Lithology}

In addition to slope and land use/cover, permeability of the substratum is another factor which greatly influence DRP in an area. The permeability of substratum determines the rate at which water infiltrates into the subsurface. Where the substratum is highly permeable, surface water infiltration is high resulting in DP, whereas in places where substratum is impermeable SOF or SSF tend to develop depending on the slope. The geologic map of the study area 
produced by The Nigerian Geological Survey in 2006 was georeferenced and digitized. The lithology's in the study area are: Alluvium, Clay-shale and sandstones, coal, shale and loose sands, mudstones, sandstones and lignite, siltstone, sands and sandstones (Figure 3). The lithology's were classified as either permeable or impermeable based on their characteristics.

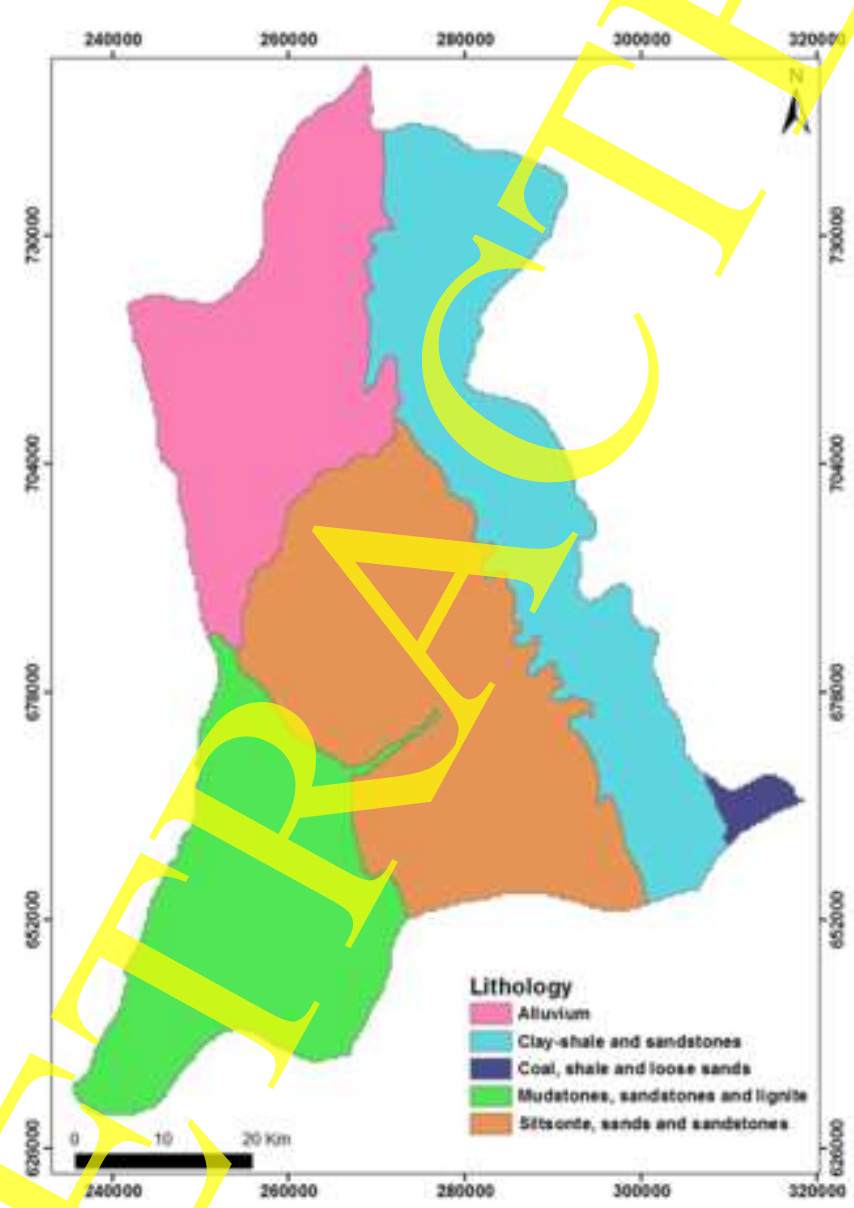

Fig.3. Geological map of the study area. (Adapted after Nigerian Geologic Survey Agency, 2006)

The classification of the lithology's into permeable/impermeable is based on the Formation it belongs and dominant unit present. Siltstone, sands and sandstones belongs the Bende Ameki Formation including Nanka Sands. Clay-shale and sandstone belong to Imo Shale Formation with Ebenebe 
sandstone. Coal, shale and loose sands belong to the Lower Coal Measure. Mudstones, sandstones and lignite belong to the Lignite Series (NGSA, 2006). Imo shale Formation with Ebenebe sandstone, Lower Coal Measure and Lignite Series were classified as impermeable while Bende Ameki Formation including Nanka Sands and Alluvium were classified as permeable.

The spatial coverage of each lithology is provided is Table 3 .

The three factors: slope, geology and land use/cover were converted into vector for data integration. Union vector overlay analysis was used to integrate the three factors to determine the DRP in the study area. The integration of the factors to identify DRP was based on the classification in Table 4.

Table 3. Area cover by different rock types

\begin{tabular}{lll}
\hline Lithology & Area & Percent area \\
& $\mathrm{Km}^{2}$ & $\%$ \\
\hline Alluvium & 974.9 & 21.3 \\
Clay-shale and sandstones & 1156.3 & 25.2 \\
Coal, shale and loose sands & 42.4 & 0.9 \\
Mudstones, sandstones and lignite & 993.3 & 21.6 \\
Siltstone, sands and sandstones & 1421.6 & 31.0 \\
\hline
\end{tabular}

Table 4. The assumed dominant runoff processes (DRP) based on slope and permeability of the substratum for grassland, arable land and forest (After Müller et al., 2009)

\begin{tabular}{|c|c|c|c|}
\hline $\begin{array}{l}\text { slope } \\
\%\end{array}$ & $\begin{array}{l}\text { Impermeable substratum } \\
\text { Grass -and arable land }\end{array}$ & $\begin{array}{l}\text { Imperneable substratum } \\
\text { Forest }\end{array}$ & $\begin{array}{l}\text { Permeable substratum } \\
\text { Grass-, arable land and } \\
\text { forest }\end{array}$ \\
\hline $0-3$ & DsOF3 & DsoF3 & $D_{D P}$ \\
\hline $3-5$ & DSOF2 & $D_{\text {SSF3 }}$ & Dop \\
\hline $5-20$ & $D_{S S F 2}$ & $D_{S S F 2}$ & $D_{D P}$ \\
\hline $20-40$ & DSSF: & $D_{S S F 2}$ & $D_{D P}$ \\
\hline$>40$ & $\mathrm{D}_{\mathrm{SS}}$ & DSSE: & $D_{D P}$ \\
\hline
\end{tabular}

\section{RESULTS AND DISCUSSIONS}

The DRPs for the study area generated through the integration of slope, geology and land use/cover of the study area is presented in Figure 4 while the statistics for the DRPs is presented in Table 5. The Hortonian Overland Flow covers the largest area within the study area with an area coverage of 1508.3 
$\mathrm{Km}^{2}(33.5 \%)$. This is due to the prominence of built-up area underlain by compact permeable formation. The prominence of built-up in this area can be linked to availability of groundwater which may be accessible through various means.

Deep percolation covers the second largest area of $1455.3 \mathrm{Km}^{2}(32.3 \%)$ occurring largely in area underlain by alluvium. This shows that considerable amount of rainfall is infiltrated for groundwater recharge. Areas characterized by DP will have abundant groundwater that can serve for several purposes. SSF covers an area of $920.6 \mathrm{~km} 2(20.4 \%)$ of the study area, due to the shallow depth of the soil and presumably lateral flow paths of water. This amount can also contribute to groundwater recharge and sometimes burst out as springs to the nearby river channel. SOF covers the lowest area coverage of $618.14 \mathrm{~km} 2$ $(13.7 \%)$ of the study area due to appreciable degree of soil saturation and filled depression storage.

Table 5. Spatial distribution of dominant runoff process

\begin{tabular}{|c|c|c|}
\hline DRP & $\begin{array}{l}\text { Area } \\
\mathrm{Km}^{2}\end{array}$ & $\begin{array}{c}\text { Percent area } \\
\%\end{array}$ \\
\hline$D_{D P}$ & 1455.3 & 32.3 \\
\hline$D_{\text {HOF }}$ & 1508.3 & 33.5 \\
\hline D $_{\text {SOF2 }}$ & 348.0 & 7.7 \\
\hline D $_{\text {SOF3 }}$ & 270.4 & 6.0 \\
\hline$D_{S S F 1}$ & 5.8 & 0.2 \\
\hline$D_{\text {SSF2 }}$ & 661.9 & 14.7 \\
\hline$D_{\text {SSF3 }}$ & 252.9 & 5.6 \\
\hline
\end{tabular}

The combined total area covered from the delineated DRPs (HOF, SSF and SOF) will support flooding, erosion, and worst environmental conditions in the nearest future if the present precipitation persists coupled with its associated urban growth rate. The groundwater characteristic for DP need to be safeguarded for its sustainable use. 


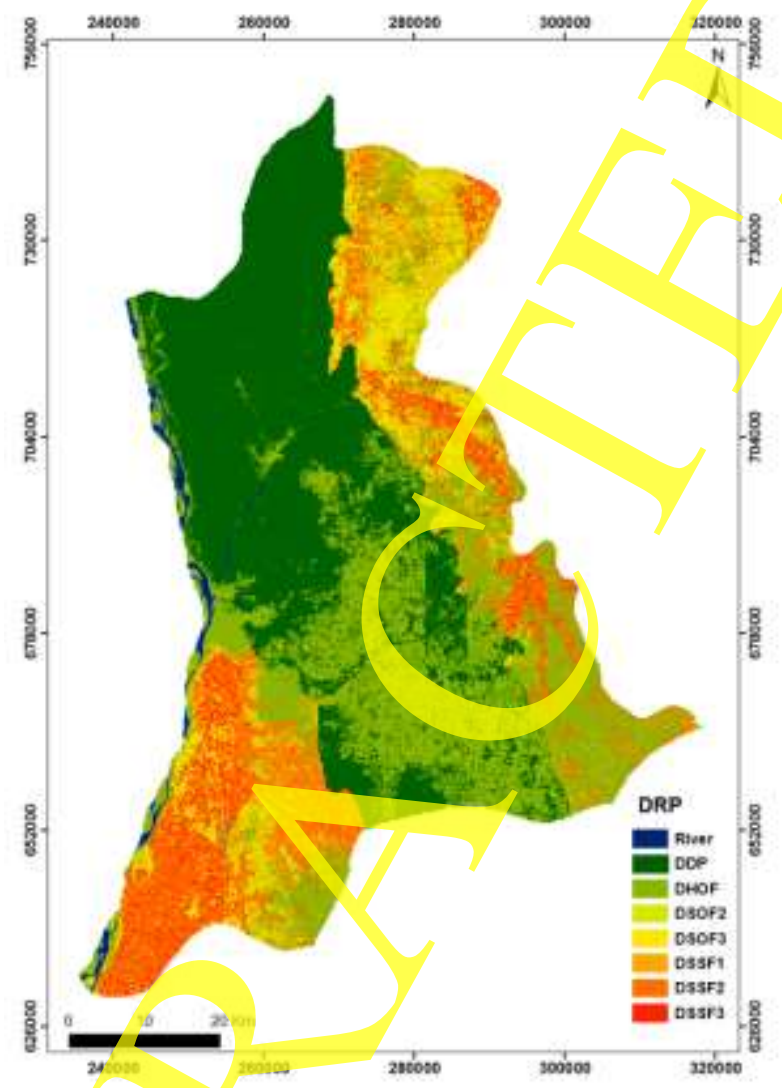

Fig. 4. Dominant Runoff Process Map of the study area

\section{Conclusions}

The objective of this study was to identify Dominant Runoff Processes (DRPs) at a regional scale for Anambra State. To achieve this, three factors namely slope, land use and geology which majorly influence runoff process were combine in a GIS environment to determine the DRPs in the study area. A simplified approach involving evaluation permeability of substratum in combination with slope and land use classification was adopted. This approach was preferred because it gives higher accuracy and requires less input data as weil as shorter computation time when compared to other GIS based approaches. Although the approach is a straight forward and fast method for delineation of DRPs, it however gives acceptable accuracy particularly at mesoscale basin level when compared to other approaches. The approach offers a method to 
delineate DRPs where necessary information such as soil maps and soil profiles are lacking. The delineated DRPs (HOF, DP, SSF and SOF) with Hortonian Overland Flow having the highest area coverage of $1508.3 \mathrm{~km}^{2}(33.5 \%)$ followed by Deep Percolation with area coverage of $1455.3 \mathrm{~km}^{2}(32.3 \%)$, Subsurface Flow with total area coverage of $920.6 \mathrm{~km}^{2}(20.4 \%)$ while Saturated Overland Flow having the least coverage area of $618.4 \mathrm{~km}^{2}(13.7 \%)$. It is presumed that considerable amount of precipitated water would be infiltrated into the subsurface thereby contributing to groundwater recharge in the study area. Validation of the derived DRPs from this study however could not be done as there is no existing DRP map for the study area

Considering the combined area covered by HOF and SOF, and the changing rainfall pattern associated with climate change, it is imperative that proper planning be considered for groundwater recharge in order to ensure its sustainable use in the future. The result of this study can be useful for relevant environmental management agencies in evaluation of groundwater recharge and monitoring of erosion and deposition rates with the view of future planning in the study area.

The results of this work have important implications in terms of flood management, groundwater recharge and regional soil conservation. The main contributions of this work can be summarized as follow: $i$ ) contribution to flood hazard mitigation: this study provides an overview of the dominant runoff processes in the study area which can be relevant for mitigation of flash floods commonly associated with HOF in built up area; ii) contribution to the field of hydrogeology: understanding of the dominant runoff processes occurring in an area is crucial for prediction and estimation of groundwater recharge which is crucial for sustainable use of groundwater resource: iii) contribution to the field of soil conservation: one of the major environmental problems in the study area is soil loss due to water erosion which has resulted in the developments of gullies and Badlands. Identification of the dominant runoff processes prevailing in different parts of the study area can help in the development of and implementation measures against soil erosion.

\section{References}

Aladejana, O. O., Anifowose, A. Y. B., and Fagbohun, B. J. 2016. Testing the ability of an empirical hydrological model to verify a knowledge based groundwater potential zone mapping methodology. Modelling Earth Systems and Environment, 2: 174. doi 10.1007/s40808-016-0234-3

Antonetti, M., Buss, R., Scherrer, S., Margreth, M., and Zappa, M. 2016. Mapping dominant runoff processes: an evaluation of different approaches using 
similarity measures and synthetic runoff simulations. Hydro1. Earth Syst. Sci., 20, 2929-2945. doi:10.5194/hess-20-2929-2016

Bonell, M.1998. Selected challenges in runoff generation research in forests from the hillslope to headwater drainage basin scale. Journal of the American Water Resources Association 34 (4), 765-785.

Faeh, A. O. 1997. Understanding the processes of discharge formation under extreme precipitation; A study based on the numerical simulation of hillslope experiments, Mitteilung der Versuchsanstalt für Wasserbau, Hydrology und Glaciology, ETH Zürich, 150.

Fagbohun, B. J., Anifowose, A. Y. B., Odeyemi, C., Aladejana, O. O., and Aladeboyeje, A. I. 2016. GIS-based estimation of soil erosion rates and identification of critical areas in Anambra sub-basin, Nigeria. Modelling Earth Systems and Environment, 2: 159. doi 10.1007/s40808-016-0218-3

Gharari, S., Hrachowitz, M., Fenicia, F., and Savenije, H. H. G. 2011. Hydrological landscape classification: investigating the performance of HAND based landscape classifications in a central European meso-scale catchment, Hydrol. Earth Syst. Sci., 15, 3275-3291, doi:10.5194/hess-15-3275-2011.

Gideon, Y. B., Fatoye, F. B., and Omada, J. I. 2014. Sedimentological characteristics and geochemistry of Ajali Sandstone exposed at Ofe-Jiji and environs northern Anambra Basin, Nigera. Research Journal of Environmental and Earth Sciences, 6(1), 10-17.

Gliński, J., Horabik, J., and Lipiec, J. (Eds). 2011. Encyclopaedia of Agrophysics. Institute of Agrophysics, Polish Academy of Sciences, Lublin, Poland.

Hümann, M. and Müller, C. 2013. Improving the GIS-DRP approach by means of delineating runoff characteristics with new discharge relevant parameters, ISPRS International Journal of Geo- Information, 2, 27-49, doi:103390/ijgi2010027

Igwe, C. A. 2012. Gully Erosion in Southeastern Nigeria: Role of Soil Properties and Environmental Factors. In Research on Soil Erosion. Danilo Godone (Ed), InTech, doe; $10.5772 / 51020$

Müller, C., Hellebrand, H., Seeger, M., and Schobel, S. 2009. Identification and regionalization of dominant runoff processes - a GIS-based and a statistical approach. Hydrol. Earth Syst. Sci., 13, 779-792, 2009.

Naef, F., Scherrer, S., and Weiler, M. 2002. A process based assessment of the potential to reduce flood runoff by land use change. Journal of Hydrology 267, 74-79.

Nigerian Geologic Survey Agency. 2006. Geological Map of Nigeria

Nwajide, C. S. 1990. Cretaceous sedimentation and palaeogeography of Central Benue Trough. In C. O. Ofoegbu (Ed.), The Benue Trough Structure and Evolution. (pp. 19-38). Braunchweig/Wiesbaden: Friedr. Viewed and Sohn

Oboh-Ikuenobe, F. E., Obi, C. G., and Jaramillo, C. A. 2005. Lithofacies, palynofacies, and sequence stratigraphy of Palaeogene strata in Southeastern Nigeria. Journal of African Earth Sciences, 41, 79-101 
Offodile, M. E. 2014. Hydrogeology: Ground water study and development in Nigeria Third Edition. Mecon Geology \& Engineering Services Ltd. ISBN: 978-309564-1

Ofomata, G. E. K. 1981. Actual and potential erosion in Nigeria and measures for control. Soil Science Society of Nigeria Special Monograph, 1, 151-165.

Onwuka, S. U., Okoye, C. O., and Nwogbo, N. 2012. The place of soil characteristics on soil erosion in Nanka and Ekwulobia communities in Anambra State. Journal of Environmental Management and Safety, 3(3), 31-50.

Reyment, R. A. 1965. Aspect of the Geology of Nigeria. University of Ibadan Press, Nigeria.

Sharma, T., Satya, K. P. V., Singh, T. P., Trivedi, A. V., Navalgund, R. R. (2001). Hydrologic Response of a watershed to land use changes. Int J Remote Sens 22(11):2095-2108

Scherrer, S. and Naef, F. 2001. A decision scheme to identify dominant flow processes at the plotscale for the evaluation of contributing areas at the catchment-scale, in: Runoff generation and implications for river basin modelling, edited by: Leibungut, C., Uhlenbrook, S., and McDonnell, J., (Freiburger Schriften fur Hydrology, 13), Freiburg, Germany, 11-16

Scherrer, S. and Naef, F. 2003. A decision scheme to indicate dominant hydrological flow processes on temperate grassland, Hydrol. Process. 17, 391-401, doi:10.1002/hyp.1131.

Schmocker-Fackel, P., Naef, F., and Scherrer, S. 2007. Identifying runoff processes on the plot and catchment scale, Hydrol. Earth Syst. Sci., 11, 891-906, doi:10.5194/hess-11-891-2007.

Selvam S, Dar FA., Magesh, NS, Singaraja, C., and Venkatramanan, S. 2015. Application of remote sensing and GIS for delineating groundwater recharge potential zones of Kovilpatti Municipality, Tamil Nadu using IF technique. Earth Sci Inform. doe 10.1007/s12145-015-0242-2 